\title{
Reentrant Softening as Precursor to Reentrant Melting of the Vortex-Lattice in YBCO Single Crystal
}

\author{
C. Hucho ${ }^{1}$, J.M. Carter ${ }^{1}$, V. Muller' ${ }^{1}$, A. Petrean ${ }^{2}$, and W.K. Kwok ${ }^{2}$
}

${ }^{1}$ Paul-Drude-Institut fur Festkorperelsktronik Hausvogtaplatz S-7 10117 Kerlin, Universitat Augsburg, Institut fur Experimentalphysik 111, Universitaissir. 1, 86135 Augsburg

${ }^{2}$ Argonne National Laboratory, Argonne, IL 60439 USA

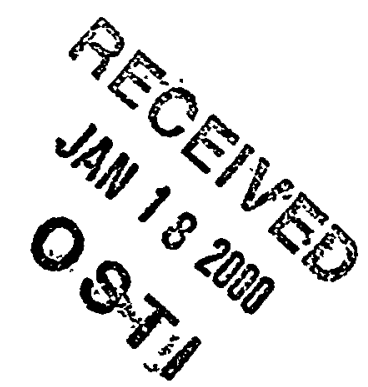

Submitted to the Vortex Conference, Crete, Sept. 18-24, 1999 for publication in Physica C

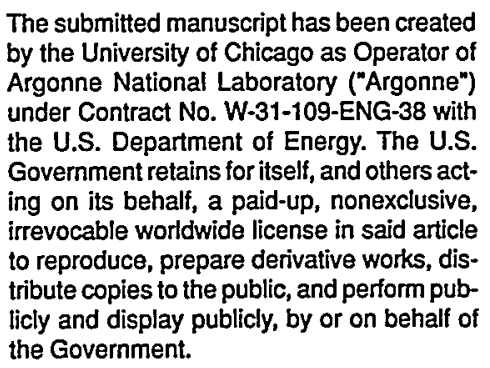

This work was supported by the U.S. Department of Energy, Basic Energy Sciences-Material Sciences Division Under Contract No. W31-109-ENG-38. 


\section{DISCLAIMER}

This report was prepared as an account of work sponsored by an agency of the United States Government. Neither the United States Government nor any agency thereof, nor any of their employees, make any warranty, express or implied, or assumes any legal liability or responsibility for the accuracy, completeness, or usefulness of any information, apparatus, product, or process disclosed, or represents that its use would not infringe privately owned rights. Reference herein to any specific commercial product, process, or service by trade name, trademark, manufacturer, or otherwise does not necessarily constitute or imply its endorsement, recommendation, or favoring by the United States Government or any agency thereof. The views and opinions of authors expressed herein do not necessarily state or reflect those of the United States Government or any agency thereof. 


\section{DISCLAIMER}

Portions of this document may be illegible in electronic image products. Images are produced from the best available original document. 


\title{
Reentrant Softcning as Precursor to Recntrant Melting of the Vortcx-l.attice in YBCO Single Crystal
}

\author{
C. Hucho, J.M. Cal1er*, V. Müller*, A. Petrean**, and W.K. Kwok**

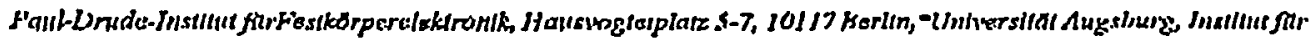

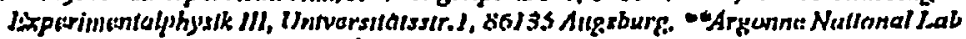

\begin{abstract}
Abstinct

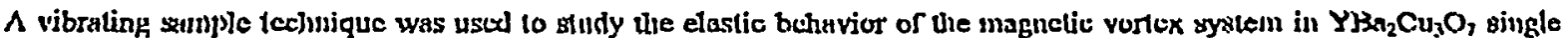

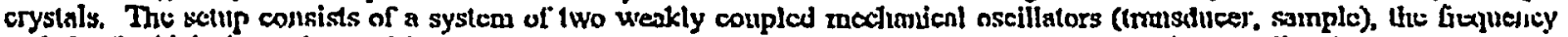
and $Q$ of which deyrends sansitively on the froquencies of the tivo sulksystems as well us the coupling betwexen buth. 13y

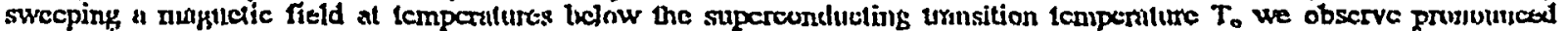

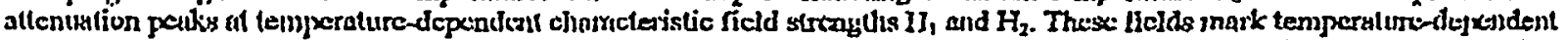

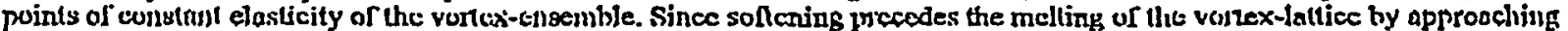

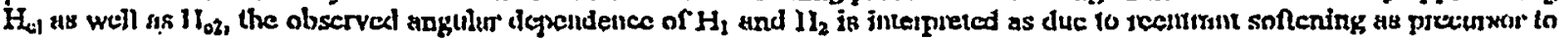
recilirant melling.
\end{abstract}

\section{Introduction}

The vortex-cnsemble in lugh-ilas superconduclors exhibits a pliasc-diagram of much higher complexity thatn oonventional bulk type-1l supcrconductors. 'This is due to a combination of intrinsic fealures such is high anisolropy, hight thermal excitation cncrgy and the possibility of a large amount of static disorder induced by a variety of defeets. Recently, a number of vortex-phases has becn proposed is explanalion for experiniental findings in the extrenely anisotmpic superconductor $\mathrm{Bi}_{2} \mathrm{St}_{2} \mathrm{CiCH}_{2} \mathrm{O}_{8}$ (c.g.[1]). Despitc increasing effor to map out the complete phasedingram of magnetic vortices in high- $T_{c}$ superconductors, however, one of the morc prominent theorelical predictions for 2-dimensional lype-ll superconduclors has nol been observed dircelly: the reentrant transition from a vortexliquid to a crystalline vortex-solid and back to the vortex-Liguid pluast upon raising the magnetic field from 0 to $H_{\alpha 2}$, the upper critical hicld. While the upper melting iransition (close to $\mathrm{H}_{02}$ ) is well establishod the lower transition escapes expertmental verification due to ils close proximity" to the lower critical field $H_{\mathrm{ol}}$. An experimental scparation or these two phasc-iransitions will be an extremely diffieult it' not impossible kask. Since a necessary prectursor to melling of the vortexensemble, huwever, is the sonening of its shear modulus $C_{156}$ [2], we attempted to deteot the recintrant soflening of the vortcs-lattice as precursior to reentrant nielting. Ulirisonic tochuigues, measuring the elastic moduli of the samples under investigation directly, appear ta be the natural tool for identifieation of the temperature- and field-

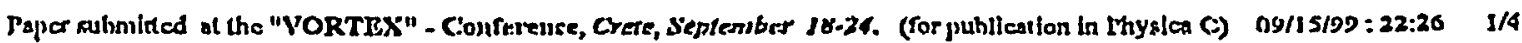


dependent elastic properties of the vortex-system. Investigation of line vortex-cnscrnble with uliressouncl, hoiveiver, requires coupling of the ultrasunic girsin-ficld in the jonic crystal-latlice to the vortices. In conventional ulinasound expcriments the alrain-ftcld omples to the magnelic nux-lines prodominintly via the vonex-pirsite interaction (strain-coupling). 'the contribution of the sound-induced motion of charge carticrs relative to the vortex-ensemble (I orenti-coupling) is usually negllgibly small. Conventiunal ultrasound expctiments, uncretore, are best suitud to sludy the temperature- and ficld-dependen! depinning transition in delect-rich superonnduetors - rather than the elastic behavior of the froc, unpinned vortex-littice. While J.l'anker, P.I.enmens and coworkers [3] were successful in identifying therntally assisted flux flow as cssentia! loss-micohanism in high-ilo superconductors, a plasse-Iransition in the vonex ensemble was not defected in ultrasound experiments. Conventional ultrasonic experintents appear to be or liktle help in detemining the propertics of the free vortexensernble.

\section{Expcrimsntul approach}

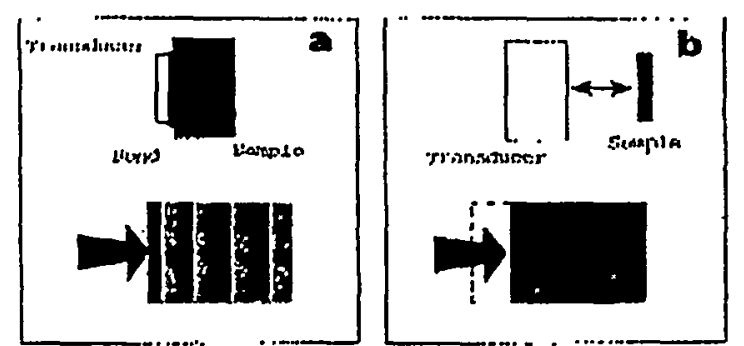

Hied: ihe diffented bawcan ultrsanic experimonis and 'm(x)iltralod sample' experitntalts (sdiematio). In conventiuginl

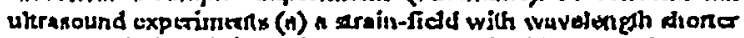
Vials Rample-fonght is excilad and dacedod wilh a trutsditcer. If Uis annjle is driven by medanical oxeillntiuns with

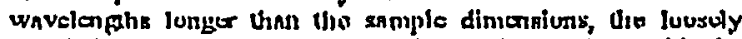
(a)tiplad sample is cuscritully moving hack and forth with tho frowuancy inyly sasted liy the transduces (b).

The crystal-Juttice and elcetronic comribution to dispersion and absorption of the soltnd-wave travelling through the sample, doninule the experimentilly obscrvable quantitics in ultrasound experiments. The expetiments presentod here aimod at reducing the contribution frum the cryslat-latice and focusing on the I vrents-oupling to the vortexsystem.

In order to roduce the strain-ficld in the mmple we modified the coliventional ultrasound-approach in (wo aspects: a) The transdicer was driven by relativcly low frequencics. Will, the transdicer's resonance-frequency at only a fow Mllz. and samples with thickncss less than 201$) \mu \mathrm{m}$, the wavelength of the mechanical oscillations was much Jarger than the sample dincnsiuns. 'The ample was essentially moving back and forth, unstrained, with the frequency inpressed by the Iransducer. The aim of prodicing a linear mollon of the sample scls this 'uceclcrated sample technique" (asi)[4] apart from experiments will high-Q oscillators operatod in a tilling mode (S]. b) the sunple was allached only looscly to the transducer surface. The setup constitutes a system of weakly corpled mechanical oscillators in which the sample is moving with a plusc-lag relative to the uriving metion of the transducer-surface. The phnse is influcnead by the coupling-strengti and by the viscous losses of the sample moving in the background of the nugrelic vortex-system. While at Iroguencies of several MHz. and displacements or 3 low $\mathrm{nm}$ the accolcration of the sample is of the order of $10^{\circ} \mathrm{m} / \mathrm{s}^{2}$, it was argucd that in a sample which is acceleraled in a homogencouss maguetic field, the motion of the bound charge-cariers and the conduction charge-camiers is striclly in plase and not leading to an altcruating not current that would intcract with the frec vortex system $[6,7]$. In a suparconductor accelerated in a hurnogeneous magnetic ficld the vortices would rest in the ftaine of the superconduclor. It was conjectured $|7|$ that periodic tilting of the sample duc to iutrinsic nonvanishing asymmetrics in the setup would more casily cxplain the obscrued temperature- and fielddependent losses. Whilc this moclunism does play in important role in vibrating reed expcriments, we would ljke lo draw attention to expcriunents by R.C. Folmin and T.D. Stewart [8], who were among the tirst to determinc the incrita of conduction cloctrolis in inctals by mcasuring the voltagc-drop acruss acoleratod metils in the absence of a mugnetic fleld. The uocelcration of thcir sumples was 2-3 orders or magnitude lower them in the exporiments 
presentod hers. In these experinicnts we find Justirication for our assumption that an sceviluration-inducod ac-net-current could provide for a cmupling moditnism betrecn the mochanianl oscillations of tho Eimple and tlic free, unjpinnod vortex-ensemble. In this case the vortices would not be at rest inside the superconductor. If the indued net current interacts wlut the vortices, lossies in the nucchonically oscillating systcm could be interpreled similar to conventional clcctrical Iransport experiments, albcit at very low current densitics. The origin of the attenuation-peaks obscricd in our cxperiments is depicted quillitatively in lig.2.

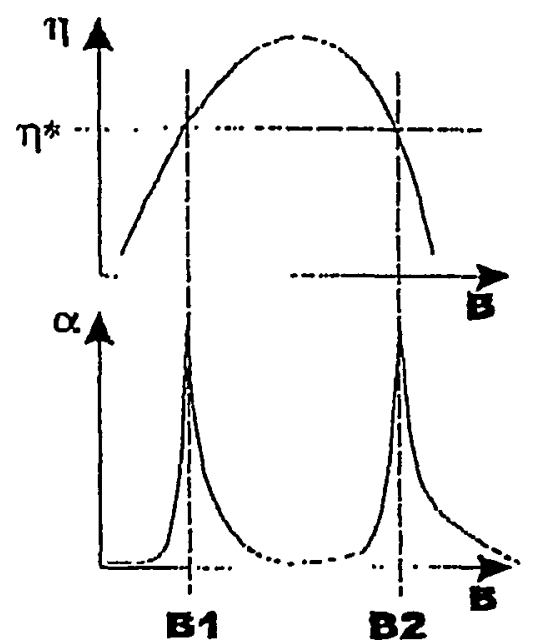

lijgra: Luic in the weak coupling betwean diluing oscillator

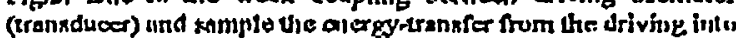

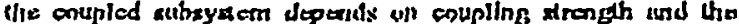
viscosity $\eta$ of the beckgound. Tho fidd-dentandano of $\eta$ is whelulual as solid line in the upper voripll. Al a clusacteriatio valuo $\eta *$ the scoustit: intupedures of the couples oscillnlor is

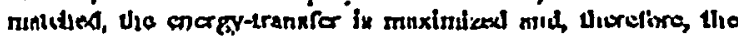
docay-rato tor the cuusiafredy oxcillating usalnsduoor in increansed

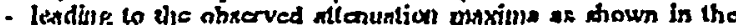

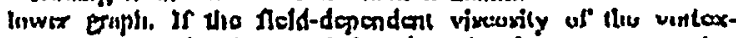

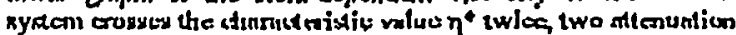

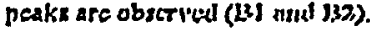

\section{Mesultx}

The sample was the snume detwinned YBCO single crystal $\left(T_{c}-93 K\right)$ that was used in refl3). The sample was mounled to the iraisducer so that the crystal was uscillating back and forth parallel to the c-axis. The sample thicknass was $-0,15 \mathrm{~mm}$. The transducer was excited with a If-electrontagnelle pulse of $3 \mathrm{MH} \%$ and $\mathrm{Sms}$ duration. The decuying sigalal anter swirching ofr the pulse wus munitored with a digital oscilloscope. From the envelopo of the dccaying sigmil the altenuation was determinod. Alter cooling the sample to $80 \mathrm{~K}$ in $\%$ cro niggnetic ficld, the teingerature was stabiliced and data were rccorded on increasing field. The main results are presented in fig.3. On imcreasing licld a pronounced attcnuation peak appents at a cluaructeristic nuxdensity $B_{1}$. The atienuation pesk moves to lower ficlds with decreasing angle $\theta$ between ficld and $a-$ uxis of the crystal. With further reduction of $\Theta$ y second atlenuation peak appears at higher fields (cotresponding to $\mathrm{B}_{2}$ in $\mathrm{ng} .2$ ). The two puaks limally move tugelher, merge and disapyear. These attcnuation peiks originate in (acuustic) impedance-matching between the transilucer and the oscillating sample at a rixed value of the angular dependent shear modulus $\mathrm{C}_{r}(\mathrm{~B}, \Theta)$. Since $\mathrm{C}_{6 \sigma}-1 \mathrm{I} / \mathrm{II}_{\mathrm{c} 2}$ at Iow holds and $\left(1-\mathrm{H} / \mathrm{H}_{02}\right)^{2}$ at ligh fields [II], the matching conditions are fulfilled twice in one ficld-swcep from $\mathrm{O}$ to $\mathrm{H}_{\mathrm{o} 2}$, leading to the obserycd double-peak struchure. This interpretation is corroborated oy the observation thist the angular dependence of the attenuationpesks is consistent with the angular-dcpendence of $C_{66}$ at constant ficld: $C_{66}(\Theta)-l / e$ for motion perpendicular to the CuO planes (the mugledependent unisotropy parameter $e$ is defined as $\left.\varepsilon^{2}-1 / 50 * \sin ^{2} \theta+\cos ^{2} \theta\right)$ [2]. 

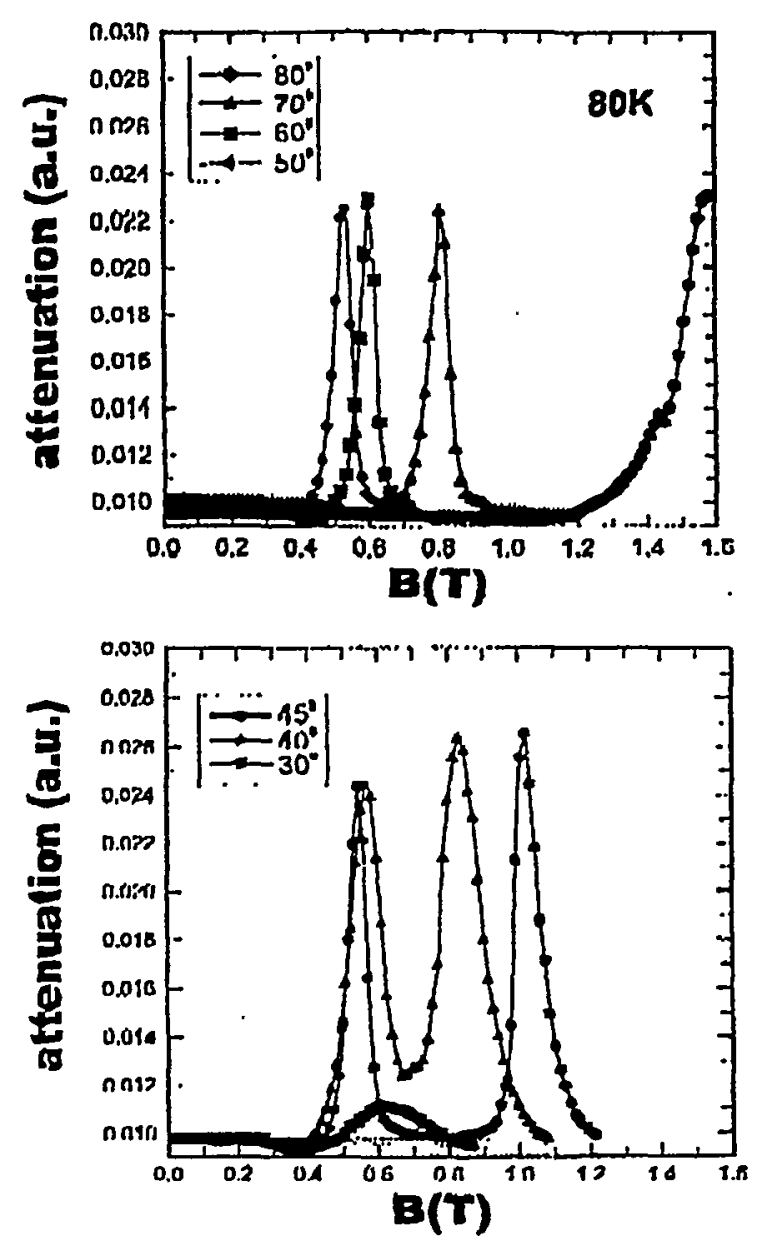

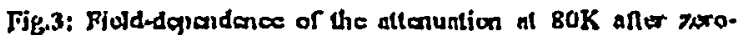

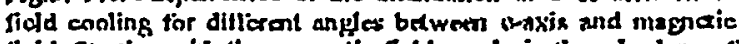

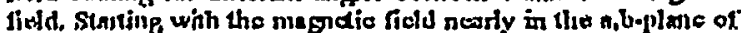
the rumple, the nttcemation-j)ak nnver lo lower chnracteristic

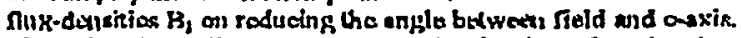

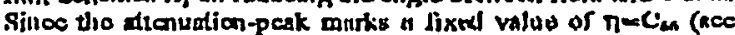

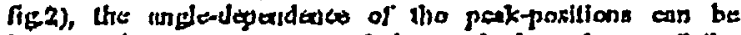

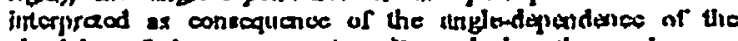
whaticiny of the vorex-ryadem by reclueing the argeglo oven

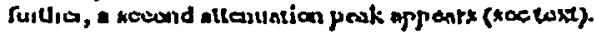

\section{Conclukions}

In summary, we Jave shown that a modiffeation of ultrasound cxporiments, tho acceleraied simple leclunique, is a powerful tcchnigute to gain insight into the ficld- and angledependence of the shenr-modulus of the 'froc," unpinned vortex-systcm. From the discussion given above, the observed attcnuation-pcaks could in principle lunve their origin in a second efreet: a ficld-induced cluange in the coupling-sireugth belween samplo and tratisducer, originating in a torgue acting on the sample. 'The obscrved angledependenoc of $B_{1}$ and $B_{2}$, howeycr is not consistent with this nechanism [10]. The observed recntrant sollening or the vorex-lattice is the origin for a number of recntraill secondary efrects, such as c.g. the rccntrant irreversibility-linc as observed in modified torque expariunents[12].

By using different symmetrics in the setup we arc actually able to obscric both effects separately. $\Lambda s$ will be prescnted elsewhere[9], a sclup similar to the one deseribed hore, but with asymmetrically mounted sample, showed an angulur dependenoc of the characieristic field $B_{1}$, that can be explained directly by the angular dependence of the lorque in YBCO [10].

\section{References}

[1] D.T. Fudis, li.Zaluov a al., Shys.Rev.l.ott. 40 (22), 4971 (1948)

[2] Ci.blaller d ol., Jev. Mod. Phys. 66, 1125 (1994)

[3] .1. Pankar, y. I eminens d al., J'hysJlov.lell 65, 3 us2 (10v0)

[4] C.Indio and M.I cvy, Phys.lRevLein 77 (7), 1370 . (1996)

[5] C.A. Jollo d al, Nature, 394, 43 (1999)

$10\}$ L. Surnin, juivertio onmumunication.

[7] Fill. Brand, privato communication

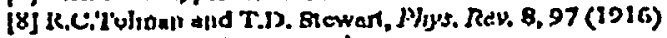

19) C..Luadio al.. in proparations

[In] V.Ci.Kogan, Jhys.RevD, 38 (10), 7019 (j988)

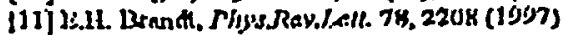

[12] M.Willemin al ul., l'hys.Rev.R, 5R, R5940 (1908) 